\title{
Relationship between testicular blood flow, testosterone secretion and spermatogenic activity in young and adult wild red foxes (Vulpes vulpes)
}

\author{
M. Joffre \\ Laboratoire de Physiologie Comparée, Faculté des Sciences, Parc Grandmont, \\ 37200-Tours and Centre d'Etudes Biologiques des Animaux Sauvages, \\ 79360-Beauvoir-sur-Niort, France
}

\begin{abstract}
Summary. Testicular capillary blood flow (TCBF) was measured by the radioactive inert gas clearance technique throughout the reproductive life of young adult foxes and was related to the spermatogenic and androgenic activities of the testis. Mean ( \pm S.E.M.) blood flow $\left(\mathrm{ml} \mathrm{min}^{-1} \mathrm{~g}^{-1}\right.$ ) was maximal in January in adults during the mating period $(0.65 \pm 0.03)$, and in pubertal animals $(0.62 \pm 0.04)$. At this time spermatozoa were observed in the testes of all animals, but testicular weight and circulating testosterone levels were lower in the pubescent foxes than in the adults. TCBF was minimal during immaturity $(0.29 \pm 0.03)$ and during the resting period of the adult $(0 \cdot 12 \pm 0 \cdot 01)$. These values were associated with a low testosterone level and with the multiplication of gonocytes in the young or with the seasonal very low spermatogenic activity in the adult. During the prepubertal period, TCBF slowly increased and was accompanied by testicular growth. In the adult, in September, TCBF rapidly increased without changes of testicular size and then slowly increased as the testes enlarged. High plasma testosterone concentrations occurred later. During the period of testicular regression, TCBF, testicular size, spermatogenic and androgenic activities decreased together.
\end{abstract}

\section{Introduction}

The fox is a seasonal breeder and the changes in the reproductive organs of young and adult male foxes have been described (Rowlands \& Parkes, 1935; Creed, 1960; Fairley, 1970; Joffre, 1976a). The young are born in March, the prepubertal period starts in October, and puberty occurs in January at the end of the first year of life. The adult fox has a well defined breeding season, extending from December to February, after which the testes rapidly regress and remain quiescent from May to September. Testicular blood flow has been studied (see Setchell, 1970), but its relationship with spermatogenesis or hormonal secretion is poorly understood. In the present study, testicular capillary blood flow (TCBF) was determined in foxes and attempts were made to relate the pattern of TCBF to testicular weight and to the spermatogenic activities of the testis.

\section{Materials and Methods}

Foxes (Vulpes vulpes) were caught in south-western and mid-western France and were individually caged under normal daylight and temperature conditions. The animals were fed with dead chickens and were allowed free access to water. The foxes lived uneventfully under these conditions; no important differences in the reproductive activity between wild foxes and those reared in captivity have been observed (Joffre, 1976a). 
Testicular capillary blood flow was measured by a radioactive inert gas clearance technique (Joffre, M. \& Joffre, J., 1971; Joffre, J. \& Joffre, M., 1973) on 96 foxes, 46 of which were immature or prepubertal. They were anaesthetized with an intraperitoneal injection of sodium barbital $\left(15 \mathrm{mg} / \mathrm{kg}\right.$ ), and xenon-133 (Xe 133-S $\mathrm{S}_{1}$ : I.R.E.Belgium; sp. act. $70-100 \mathrm{mCi} / \mathrm{ml}$ ) in saline solution $(0.01-0.02 \mathrm{ml})$ was injected directly into the testis through the scrotum with an intradermal needle ( 29 gauge). Foxes were used at approximately monthly intervals between 1 and 24 months of age, and they were then castrated to check the spermatogenic state of the testis histologically.

In these conditions, the clearance curves showed two components: a fast one, which has been previously shown to be related to testicular blood flow, and a slow one representing blood flow in the epididymal fat (Joffre, M. \& Joffre, J., 1971). Since the partition coefficient of ${ }^{133}$ Xe between the testis and blood depends on the lipid content (Yeh \& Peterson, 1965), lipid was measured by Folch's technique (Folch, Lee \& Sloane-Stanley, 1957). The lipid values $(\mathrm{mg} / 100 \mathrm{~g}$ testis) were 4.95 (pool of 4 testes) for young foxes and $4.45 \pm 1.33(n=20)$ and $7.95 \pm 4.48(n=15)$ for adult foxes in and out the breeding season respectively: the differences were not significant. The partition coefficient of xenon $(\lambda)$ has not been determined for the fox testis. The value given by Fritjofsson, Persson \& Pettersson (1969) $(\lambda=0.82)$ for the human testis, which is structurally very similar to the fox testis (Joffre, 1976b), was used to determine the TCBF of foxes by the formula of Kety (1951). The specific gravity of the testis $(\rho)$ was determined on 65 foxes and no changes were found throughout the reproductive life $(1.063 \pm 0.005 \mathrm{~g} / \mathrm{ml})$.

Plasma testosterone levels were determined by the radioimmunoassay method of Leymarie, Strauss \& Scholler (1974), validated for the fox by Joffre, M. \& Joffre, J. (1975), in blood samples collected from the radial vein, just after the determination of TCBF. The antibody was raised in a rabbit against testosterone-3-(O-carboxy)-methyloxine-BSA and the working range of the assay was 5-140 pg. The inter- and intra-assay variations were $3.2 \%$ and $7 \cdot 3 \%$ respectively; each sample being estimated in duplicate. The spermatogenic activity of the testis was estimated from its weight (Joffre, 1976a) and histology at the time of autopsy.

Statistical significance was determined by using the Student's $t$ test. Correlation techniques were used to evaluate the relations between TCBF and testicular weight or plasma testosterone throughout the year.

\section{Results}

The variations of TCBF, measured at monthly intervals, in young and adult foxes are shown in Table 1.

Table 1. Seasonal changes of mean \pm S.E.M. testicular capillary blood flow ( $\mathrm{ml} \mathrm{min}^{-1} \mathrm{~g}^{-1}$ ) of young and adult anaesthetized wild red foxes (no. of measurements in parentheses)

\begin{tabular}{|c|c|c|c|c|c|c|c|c|c|c|c|c|}
\hline & July & Aug. & Sept. & Oct. & Nov. & Dec. & Jan. & Feb. & March & April & May & June \\
\hline $\begin{array}{l}\text { Young } \\
\text { foxes }\end{array}$ & $\begin{array}{l}0.34 \pm \\
0.04 \\
(9)\end{array}$ & $\begin{array}{c}0 \cdot 25 \pm \\
0 \cdot 03 \\
(26)\end{array}$ & $\begin{array}{c}0 \cdot 31 \pm \\
0 \cdot 03 \\
(25)\end{array}$ & $\begin{array}{l}0.38 \pm \\
0.03 \\
(51)\end{array}$ & $\begin{array}{c}0.42 \pm \\
0 \cdot 03 \\
(44)\end{array}$ & $\begin{array}{l}0.46 \pm \\
0.04 \\
(29)\end{array}$ & $\begin{array}{l}0 \cdot 62 \pm \\
0 \cdot 04 \\
(38)\end{array}$ & \multirow{2}{*}{$\begin{array}{l}0.50 \pm \\
0.03 \\
(56)\end{array}$} & \multirow{2}{*}{$\begin{array}{c}=0.27 \pm \\
0.02 \\
(23)\end{array}$} & \multirow{2}{*}{$\begin{array}{c}0.22 \pm \\
0.02 \\
(69)\end{array}$} & \multirow{2}{*}{$\begin{array}{l}0.12 \pm \\
0.01 \\
(37)\end{array}$} & \multirow{2}{*}{$\begin{array}{c}0.10 \pm \\
0.01 \\
(85)\end{array}$} \\
\hline $\begin{array}{l}\text { Adult } \\
\text { foxes }\end{array}$ & $\begin{array}{c}0.18 \pm \\
0.02 \\
(30)\end{array}$ & $\begin{array}{c}0.14 \pm \\
0.02 \\
(23)\end{array}$ & $\begin{array}{c}0.32 \pm \\
0.02 \\
(29)\end{array}$ & $\begin{array}{c}0.31 \pm \\
0.02 \\
(29)\end{array}$ & $\begin{array}{l}0.34 \pm \\
0.03 \\
(19)\end{array}$ & $\begin{array}{l}0.43 \pm \\
0.04 \\
(19)\end{array}$ & $\begin{array}{l}0.65 \pm \\
0.03 \\
(72)\end{array}$ & & & & & \\
\hline
\end{tabular}

\section{TCBF and spermatogenic activity}

As shown in Text-fig. 1, TCBF and testicular weight are closely correlated during the reproductive life of young and adult foxes $(r=0.67 ; P<0.01)$, except during the prepubertal period of the young and, in September, at the beginning of the period of testicular regrowth of the adult when TCBF increases before testicular weight. 


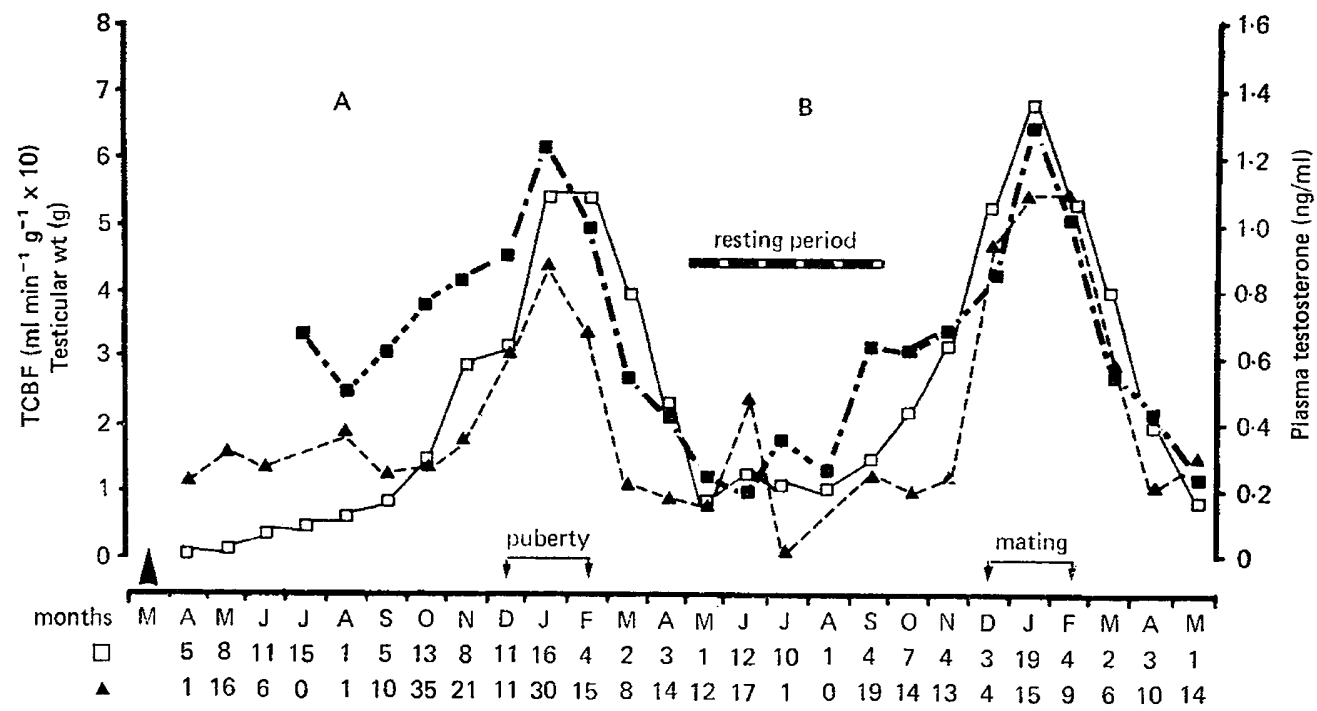

Text-fig. 1. Seasonal changes (monthly means) of testicular capillary blood flow ( $\square$ ), testicular weight ( $\square$ ) and plasma testosterone levels $(A)$ in young $(A)$ and adult $(B)$ red foxes. The figures along the horizontal axis represent the number of animals studied in each month. See Table 1 for numbers involved in TCBF measurements. Arrow indicates time of birth.

It was not possible to determine the TCBF of young foxes until June because of the difficulty of locating the testis under the scrotum and its small size for injecting xenon. From July until October, while the testis was slowly growing and gonocytes were multiplying, TCBF did not vary significantly $\left(0.29 \pm 0.03 \mathrm{ml} \mathrm{min}^{-1} \mathrm{~g}^{-1}, n=60\right)$. In October, when TCBF and testicular weight began to increase, spermatogonia, primary spermatocytes, spermatids and spermatozoa appeared in the seminiferous tubules. In January, TCBF reached a maximum value and the foxes were then pubescent, testicular weight also being maximal ( $5358 \pm 207 \mathrm{mg}, n=16)$ and numerous spermatozoa were present in the seminiferous tubules. From February until May, TCBF and testicular weight progressively decreased and, at the beginning of this period, spermatogenesis ceased, leaving degenerate cells in the tubule lumina which were evacuated through the epididymis. In March, only a few primary spermatocytes were observed in the seminiferous tubules. From May until September, the resting period, testicular weight was low $(1122 \pm 54 \mathrm{mg}, n=24)$, the TCBF was very much lower than the values in immature foxes $\left(0 \cdot 12 \pm 0.01 \mathrm{ml} \mathrm{min}-1 \mathrm{~g}^{-1}, n=125, P<0.01\right)$ and there was little mitotic activity in the seminiferous tubules which contained few primary spermatocytes (zygotene), spermatogonia and, sometimes, only Sertoli cells. Then, in September, sometimes in August, TCBF rapidly increased $(P<0.01)$ but there was no concomitant increase of testicular weight. At this time, TCBF values were very similar to those of prepubertal foxes at the same period of the year. Many primary spermatocytes were present in the seminiferous tubules of 4 foxes killed at this time and spermatogenesis proceeded actively. In January, during the mating period, TCBF reached its maximum value and was associated with the highest testicular weight $(6759 \pm 350 \mathrm{mg}, n=19)$ and full spermatogenesis. From October to January, during the prepubertal period and the period of testicular regrowth of the adult, fluctuations of TCBF tended to occur simultaneously in both testes of an individual but these rarely coincided in different foxes. Temporary changes of TCBF were observed during the resting period of the adult, but they were never observed on consecutive days.

\section{TCBF and androgenic activity}

TCBF and plasma testosterone levels were closely correlated at all times $(r=0.61, P<0.01)$, except during the period of testicular regrowth of the adult when the TCBF increased before the 
testosterone level altered. High TCBF values were normally associated with high testosterone levels and the presence of spermatozoa in the seminiferous tubules but, during the resting period, high levels of testosterone were sometimes associated with a low TCBF and vice versa.

\section{Discussion}

The radioactive inert gas clearance technique was considered to give an exact measurement of TCBF (Setchell, 1970), but Einer-Jensen (1974), by using a miniature Geiger-Muller tube inserted into the testis, has shown that the xenon recirculates and that only the first fast component of the clearance curve (range 1 to $5 \mathrm{~min}$ ) gives a suitable value of TCBF, confirming our previous results (Joffre, M. \& Joffre, J., 1971). In rats (Joffre, M. \& Joffre, J., 1971) and rams (Courot \& Joffre, 1976), this technique gives blood flow values similar to those of other techniques (Setchell, 1970). However, this is the only method available when repeated measurements of TCBF have to be made in the same animal throughout the year, as in the present study.

TCBF is very high during the mating period of the adult when numerous spermatozoa are present in the seminiferous tubules and there are high levels of testosterone circulating in the peripheral plasma. All the present results corroborated those previously published (Joffre, J. \& Joffre, M., 1973), but the values for TCBF are higher than those determined in other mammals (Setchell, 1970), including ferret, dormouse (Joffre, J. \& Joffre, M., 1973) and European badger (M. Joffre, unpublished data). This may be related to the short duration of the breeding period and the consequent need for a high nutrient blood flow as well as the profuse vascular system in this species (Joffre, $\mathbf{M}$. \& Kormano, 1975). At puberty, TCBF is lower than that previously reported (Joffre, M., 1973a), because all clearance curves were re-investigated and some were excluded because of the possibility of the testis being hyperaemic. The maximal values in the pubescent and adult fox were similar despite the differences of testicular weight and testosterone levels in such animals. The low TCBF value in immature foxes is higher than that determined for lambs (Courot \& Joffre, 1976) or young rats (J. Joffre, unpublished data). During the resting period of the adult, TCBF is minimal and is $2 \frac{1}{2}$ times lower than TCBF in immature foxes, although the testicular weight is twice as great.

In mammals, TCBF is under nervous control (Setchell, 1970), but it seems unlikely that seasonal changes of TCBF are regulated by catecholamines. Nevertheless, the simultaneous temporary changes observed in both testes of young and adult foxes from October to January might be induced by catecholamines released during stress induced by handling of the animals. In the ram, a decrease of body weight after a long period of undernutrition lowers the total blood flow per unit of testicular weight (Setchell, Waites \& Lindner, 1965). There are no seasonal changes in the body weight of the adult fox and, in the young, the increase of TCBF occurs while the body weight approaches the adult value. Changes of TCBF have been observed during the breeding cycle of other mammals (Joffre, J. \& Joffre, M., 1973 ; Courot \& Joffre, 1976), but changes of TCBF during the prepubertal period have not been found for rabbits (Larson \& Foote, 1974) or lambs (Courot \& Joffre, 1976).

The regulation of capillary blood flow is under metabolic control in numerous vascular beds (Haddy \& Scott, 1975). It is generally agreed that the TCBF varies only slightly in the testis while testicular metabolism changes (Waites \& Setchell, 1969a, b; Setchell, 1970). Nevertheless, TCBF does appear to be correlated with the metabolism of the gonad in the fox: in September, the increase of TCBF occurs with the onset of spermatogenesis, without growth of testicular size and despite the low testosterone level, suggesting that TCBF is primarily under a pituitary hormonal and (or) metabolic control at the microvascular level.

In this study, TCBF was similar in the pubescent and adult foxes, in spite of the different testosterone levels, and in the adult TCBF increased in the autumn before the appearance of high testosterone levels. These results suggest that TCBF is independent of the androgenic activity of the testes, a supposition corroborated by the fact that injections of testosterone into adult foxes during the resting period (Joffre, M., 1977a) and of cyproterone acetate into rats (Joffre, M., 1973b) do not change the TCBF

In young and adult foxes, the changes of TCBF occur without any modification of the capillary 
network (Joffre, M., 1976b), but during the period of testicular regression in the adult and, conversely, during the growth of testis, changes of TCBF are closely associated with the appearance and the disappearance of spiral arteries in the testicular parenchyma (Joffre, M. \& Kormano, 1975). Blood pressure is known to decrease along spiral arteries (Waites \& Moule, 1960; Moll \& Kunzel, 1971,1973 ), and it therefore seems possible that the spiral arteries are the cause of the reductions in TCBF in foxes. Moreover, during testicular regression, the capsule and septa of the testis lose weight and total collagen (Joffre, M., 1977b). Except for the capillaries, most of the testicular vessels are closely associated with the capsule and septa and these appear to be responsible for the cyclic changes of testicular vessels and, consequently, of TCBF. In the rat, in which the testis is organized without septa, hypophysectomy or cryptorchidism involve no important change of TCBF (Glover, 1965; Csernay, Lazlo \& Kovacs, 1968; Setchell, Voglmayr \& Waites, 1969) and no modification of the testicular vasculature (Harrison, 1949; Kormano, 1969).

This work is a part of that submitted in a thesis for the Doctorat ès-Sciences, University of Poitiers (No.C.N.R.S.:A.O. 10796). I thank Professor G. M. H. Waites for his judicious criticism and help with the manuscript.

\section{References}

Courot, M. \& Joffre, M. (1976) Testicular blood supply in the sheep. Annls Biol. anim. Biochim. Biophys. 16, 171, Abstr.

CREED, R.F.S. (1960) Observations on reproduction in the wild red fox (Vulpes vulpes). An account with special reference to the occurrence of fox-dog crosses. Br. vet. J. 116, 419-426.

Csernay, L., Lazlo, F.A. \& Kovacs, K. (1968) The effect of hypophysectomy on adrenal, thyroid and testicular blood flow in the rat. Acta physiol. Acad. Sci. hung. 33, 291-295.

EINER-JENSEN, N. (1974) Local recirculation of ${ }^{133}$ xenon and ${ }^{\mathbf{8 5}} \mathbf{k r y p t o n}$ to the testes and the caput epididymidis in rats. $J$. Reprod. Fert. 37, 55-60.

FAIRLEY, J.S. (1970) The food, reproduction, form, growth and development of the fox (Vulpes vulpes) in North-East Ireland. Proc. R. Ir. Acad. 69, 103-137.

Folch, J., Lee, M. \& Sloane-Stanley, G.H. (1957) A simple method for the isolation and purification of total lipids from animal tissues. J. biol. Chem. 226, 497-504.

Fritjofsson, A., Persson, J.E. \& Petrersson, S. (1969) Testicular blood flow in man measured with xenon ${ }^{133}$. Scand. J. Urol. Nephrol. 3, 276-280.

Glover, T.D. (1965) Changes in blood flow in the testis and epididymis of rat following artificial cryptorchidism. Acta endocr., Copenh., Suppl. 100, 38-39.

HADDY, F.J. \& SCOTT, J.B. (1975) Metabolic factors in peripheral circulatory regulation. Fedn Proc. Fedn Am. Socs exp. Biol. 34, 2006-2011.

HARRISON, R.G. (1949) The comparative anatomy of the blood supply of the Mammalian testis. Proc. zool. Soc. Lond. 119, 325-344.

JOFFRE, J. \& JoFFre, M. (1973) Seasonal changes in the testicular blood flow of seasonally breeding mammals: dormouse (Glis glis), ferret (Mustela furo) and fox (Vulpes vulpes). J. Reprod. Fert. 34, 227-233.

JofFre, M. (1973a) Variations du débit sanguin capillaire dụ testicule au coụrṣ dẹ la période prépubère chez le
Renard mâle (Vulpes vulpes) en captivité. C. r. hebd. Séanc. Acad. Sci., Paris 277, 2731-2734.

JofFRE, M. (1973b) Débit sanguin capillaire du testicule chex le rat traité à l'acétate de cyprotérone. $C$. $r$. Séanc. Soc. Biol. 167, 1930-1934.

Joffre, M. (1976a) Puberté et cycle génital saisonnier du Renard mâle (Vulpes vulpes). Annls Biol. anim. Biochim. Biophys. 16, 503-520.

JOFFRE, M. (1976b) Débit sanguin capillaire du testicule chez le Renard roux (Vulpes vulpes). Relation avec l'activité testiculaire pendant la période prépubère et au cours du cycle saisonnier. Thèse de doctorat ès-Sci., Poitiers.

Joffre, M. (1977a) Action de HCG, PMSG et de la testosterone sur le débit sanguin capillaire du testicule de Renard adulte en période de repos testiculaire. J. Physiol., Paris, (in press) (Abstr.).

Joffre, M. (1977b) La capsule testiculaire du Renard roux (Vulpes vulpes). Relation avec l'activité testiculaire pendant la période prépubère et au cours du cycle saisonnier. Annls Biol. anim. Biochim. Biophys. (in press).

JOFFRE, M. \& JOFFRE, J. (1971) Débit sanguin testiculaire chez le Rat: mise en évidence d'une composante liée aux graisses épididymaires sur les courbes de clearance du xénon 133. C. r. hebd. Séanc. Acad. Sci., Paris 276, 496-499.

JOFFRE, M. \& JofFre, J. (1975) Variations de la testostéronémie au cours de la période prépubère du Renard et au cours du cycle génital saisonnier du Renard mâle adulte (Vulpes vulpes L). C. r. hebd. Séanc. Acad. Sci., Paris 281, 819-821.

JOFFRE, M. \& KoRMANO, M. (1975) An angiographic study of the fox testis in various stages of sexual activity. Anat. Rec. 183, 599-604.

KETY, S.S. (1951) The theory and applications of the exchange of inert gas at the lungs and tissues. Pharm. Rev. 3, 1-49.

Kormano, M. (1969) Microvascular supply of the 
regenerative rat testis following cadmium injury. Virchows Arch. path. Anat. Physiol. 349, 229-235.

LARSON, N.A. \& Foote, R.H. (1974) Testicular blood flow rates in prepubertal and adult rabbits measured by ${ }^{85}$ krypton. Proc. Soc. exp. Biol. Med.147, 151-153.

Leymarie, P., Strauss, N. \& Scholler, R. (1974) Dosage radioimmunologique rapide de la testostérone plasmatique chez l'adulte et l'enfant. Vérification de la spécificité par dosage en spectrométrie de masse. Path. Biol. 22, 877-882.

MOLL, W. \& KunzeL, W. (1971) Blood pressures in the uterine vascular system of anaesthetized pregnant guinea pigs. Pfügers Arch. ges. Physiol. 330, 310-322.

MoLl, W. \& Kunzel, W. (1973) The blood pressure in arteries entering the placenta of guinea pigs, rats, rabbits and sheep. Pflügers Arch. ges. Physiol. 338, 125-131.

Rowlands, I.W. \& Parkes, A.S. (1935) The reproductive processes of certain mammals. VIII. Reproduction in foxes (Vulpes spp.). Proc. zool. Soc. Lond. 823-841.

SeTChell, B.P. (1970) Testicular blood supply, lymphatic drainage and secretion of fluid. In The Testis
Vol. 1, pp. 101-239. Eds A. D. Johnson, W. R. Gomes \& N. L. VanDemark. Academic Press, New York.

SeTChell, B.P., WaItes, G.M.H. \& LindNER, H.R. (1965) Effect of undernutrition on testicular blood flow, metabolism and output of testosterone in the ram. J. Reprod. Fert. 9, 149-162.

SeTChell, B.P., VoGlmaYR, J.K. \& Waites, G.M.H. (1969) A blood-testis barrier restricting passage from blood into rete testis fluid but not into lymph. $J$. Physiol., Lond. 171, 411-425.

WAITES, G.M.H. \& Moule, G.R. (1960) Blood pressure in the internal spermatic artery of the ram.J. Reprod. Fert. 1, 223-229.

WAITES, G.M.H. \& SETChell, B.P. (1969a) Some physiological aspects of the function of the testis. In The Gonads, pp. 649-714. Ed. K. W. McKerns. Appleton-Century-Crofts, New York.

WaItes, G.M.H. \& SeTchell, B.P. (1969b) Physiology of the testis, epididymis and scrotum. Adv. Reprod. Physiol. 4, 1-63.

YeH, S.Y. \& Peterson, R.E. (1965) Solubility of krypton and xenon in blood, protein solution and tissue homogenate. J. appl. Physiol. 20, 1041-1047.

Received 28 September 1976 